

A99. 9

F76 72

USDA Forest Service

Research Paper INT-100

1971

U. S. DEPT. OF AGRICULTURE

NATIONAL AGRICULTURAL LIBRARY

RECFVED

DFr : $=1971$

PROCUREMENT SECTION

CURRENT SERIAL RECORDS

\section{SOIL EROSION BY OVERLAND FLOW AND RAINDROP SPLASH ON THREE MOUNTAIN SOILS}

Eugene E. Farmer and Bruce P. Van Haveren

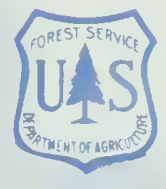




\section{THE AUTHORS}

EUGENE E. FARMER, Associate Forest Hydrologist on the Watershed Rehabilitation research work unit at Logan, Utah, joined the staff of the Intermountain Station in 1964. He holds B.S. and M.S. degrees in Forestry from the University of Idaho. He is working toward a Ph. D. degree in Watershed Science from Colorado State University.

BRUCE P. VAN HAVEREN was formerly a Forestry Aid on the Watershed Rehabilitation research work unit at Logan, Utah. He holds a B.S. degree in Watershed Science from Utah State University. He is currently doing graduate work in Watershed Science at Colorado State University.

The authors wish to thank Chester E. Jensen, mathematical statistician, of the Intermountain Forest and Range Experiment Station, Ogden, Utah, for his generous assistance with the development of the statistical models presented in this paper. 


\section{SOIL EROSION BY OVERLAND FLOW AND RAINDROP SPLASH ON}

THREE MOUNTAIN SOILS

Eugene E. Farmer and Bruce P. Van Haveren,

U.S. Department of Agriculture

Ogden, Utah 84401

Robert W. Harris, Director 


\section{CONTENTS}

INTRODUCTION . . . . . . . . . 1

METHODS AND MATERIALS . . . . . . 2

RESULTS . . . . . . . . . . . 4

Soil Erosion by Overland Flow . . . . 4

Soil Splash . . . . . . . . . 6

Erodibility Ranking by Soil Type . . . . 11

DISCUSSION . . . . . . . . . . . 13

LITERATURE CITED . . . . . . . . . . 14

\section{ABSTRACT}

This was a laboratory study of soil erosion, performed on bare soil plots under simulated rainfall. The variables having the greatest effect on erosion by overland flow were rainfall intensity, slope steepness, and the percentage by weight of soil particles greater than $2 \mathrm{~mm}$. The variables having the greatest influence on raindrop splash erosion were rainfall inteissity, slope steepness, percentage by weight of soil particles between 60 and 2,000 microns, and soil bulk density. 


\section{Introduction}

All soils erode to some degree. The rate and severity of erosional losses are primarily controlled by four classes of variables--vegetal factors, soil factors, precipitation factors, and topographic factors. Smith and Wischmeier (1962) cite vegetal cover as the greatest deterrent to soil erosion. Once the cover has been reduced below some critical level, detachment and transport of soil function together to remove the soil mantle, but at varying rates that depend upon both soil and nonsoil factors.

A voluminous amount of literature exists on soil erosion from forest and range lands. A large portion of this literature has been concerned with soil factors and their effects on erosion. Bryan (1968) worked with 22 indices of soil erodibility that have been reported in the literature. He concluded that none of the soil indices was reliable in operation and capable of universal application. He expressed doubt that such an index could be developed, but concluded that the percentage weight of water-stable aggregates greater than $3 \mathrm{~mm}$. in diameter was probably the most reliable index of soil erodibility available.

Many important questions concerning the influence of soil factors on erosion processes remain unanswered. This situation is partially due to the fact that soil factors are difficult to isolate in the presence of vegetal factors. Another difficulty has been the multiplicity of soil erosion criteria. Weight of eroded soil, numerous measures of soil aggregation, stream turbidity, measurements from various types of erosion gages, and several soil indices have all been used as erosion criteria.

In addition to vegetal cover and soil variables, the dominant factors controlling erosion are rainfall characteristics and topography. However, on forest and range lands, the effect of these two factors is not well known. Most of our information concerning rainfall factors and topographic factors has been obtained from studies on farmlands.

Wischmeier and Smith (1958) demonstrated the importance of rainfall energy to soil loss from agricultural lands. However, information on the kinetic energy of rainfall is totally absent for mountainous areas. Wischmeier (1959) and others have implied that the relationship between rainfall intensity and kinetic energy is acceptably constant in agricultural regions. No such relationship should be expected in mountainous areas of the Intermountain Region because these areas are subject to rainstorms that vary widely in those characteristics directly affecting rainfall energy; i.e., distributions of drop sizes, rainfall intensity, and wind velocities.

For most point measures of soil erosion at a given time, the precipitation factors of greatest interest are rainfall intensity, raindrop-size distribution, and total rainfall. If our interests in soil erosion expand in either time or space, the information needed must include rainfall frequency-intensity-duration relations, and deptharea-duration relations. In mountainous areas, such data are scanty.

The topographic factors of major importance to soil erosion in mountainous terrain are slope steepness and slope length. Sometimes aspect and elevation appear to be related to soil losses; although these are probably indirect effects that reflect differences in climate or vegetation, rather than topographic effects. Naturally, large variations in both slope steepness and slope length occur in mountainous areas. There is some evidence that the effects of slope length and steepness on soil erosion are interrelated with other factors, such as soil texture, soil bulk density, vegetal type, or rainfall intensity. However, most of our practical information on the effects of slope steepness has come from basic kinematic theory; e.g., the velocity of overland 
Table 1.--Results of mechanical analyses showing the average percent gravel, sand, sizt, and ciay for soils used in this study

\begin{tabular}{|c|c|c|c|c|}
\hline Soil 1 & $\begin{array}{l}: \text { Percent } \\
: \quad>2,000 \mu^{*}\end{array}$ & $\begin{array}{c}: \quad \text { Percent } \\
: \quad 2,000-61 \mu \\
\end{array}$ & $\begin{array}{r}: \quad \text { Percent } \\
: \quad 61 \mu-2 \mu \\
\end{array}$ & $\begin{array}{cc}: & \text { Percent } \\
: & <2 \mu \\
\end{array}$ \\
\hline Low-elevation granitic & 23 & 56 & 15 & 6 \\
\hline High-elevation granitic & 36 & 46 & 12 & 6 \\
\hline Wasatch clay & 0 & 21 & 28 & 51 \\
\hline
\end{tabular}

*One micron equals $0.001 \mathrm{~mm}$.

flow varies as the square root of the slope gradient and the energy of overland flow varies as the square of its velocity. Overland flow will move down a 40 -percent slope at twice the velocity of that on a 10-percent slope. By doubling the velocity, the energy of flow will increase about four times; the size of particle that can be transported will be increased about 64 times (sixth power of velocity); and the quantity of material of a given size that can be carried is increased about 32 times (fifth power of velocity).

In this paper we summarize the results of laboratory soil erosion tests performed on bare soil plots under simulated rainfall. The effects of soil, precipitation, and topographic factors were examined. Vegetation was not included because the influence of nonvegetal factors on erosion is more difficult to isolate in the presence of vegetal cover. Moreover, problem areas that exhibit high rates of soil erosion and stream sedimentation are often nearly devoid of vegetal cover. Low cover densities may result from a variety of causes; fire, logging, road construction, and grazing have been common ones in the past.

This work was intended to develop information about the effects of soil, slope, and rainfall variables on the erodibility of bare soil, to determine the magnitude of these effects, and to identify relationships between these variables.

\section{Methods and Materials}

Three soils were used in this study. Two of these, formed on weathered granitic rock, were collected in Idaho on the Boise National Forest, one at about 3,900 feet m.s.1., the other at about 7,800 feet m.s.1. The third soil, formed over limestone parent material, was collected in central Utah on the Wasatch Plateau, Manti-LaSal National Forest, at about 10,100 feet m.s.1. Only the surface inch of soil was collected. A mechanical analysis was performed on each of these soils (table 1).

These soils were each sieved through a $6.3 \mathrm{~mm}$. screen and loaded in a plot to a depth of about 4 inches. Less than 2 percent of the soil would not pass through this screen. The plot was $48 \frac{1}{8}$ by $18 \frac{1}{8}$ inches and contained no vegetation. Adequate drainage was provided from the bottom of the plot. After loading the soil, the plot was set to a specified slope $\left(2 \frac{1}{2}, 18\right.$, or 32 percent) so that the long axis of the plot pointed downhill. Average bulk-density after loading the disturbed soil was 1.14 g. per $\mathrm{cm} .^{3}$ The soil was wetted to saturation by a mist spray, covered with a plastic sheet, and allowed to drain for 20 hours. Next, constant rainfall of approximately 3 or 7 inches per hour was applied to the soil plot for 30 minutes. The actual rainfall intensity was measured during each run. The rainfall simulator used was the same as that described by Packer (1957), except that the F-type nozzles were raised to 
Figure 1.--Rainfalz simulator in operation. The plot is inclined to approximately 32 percent slope. Each of the interlocking splash trays on the floor is 9 inches wide. The nozzle rack is 12 feet above the floor.

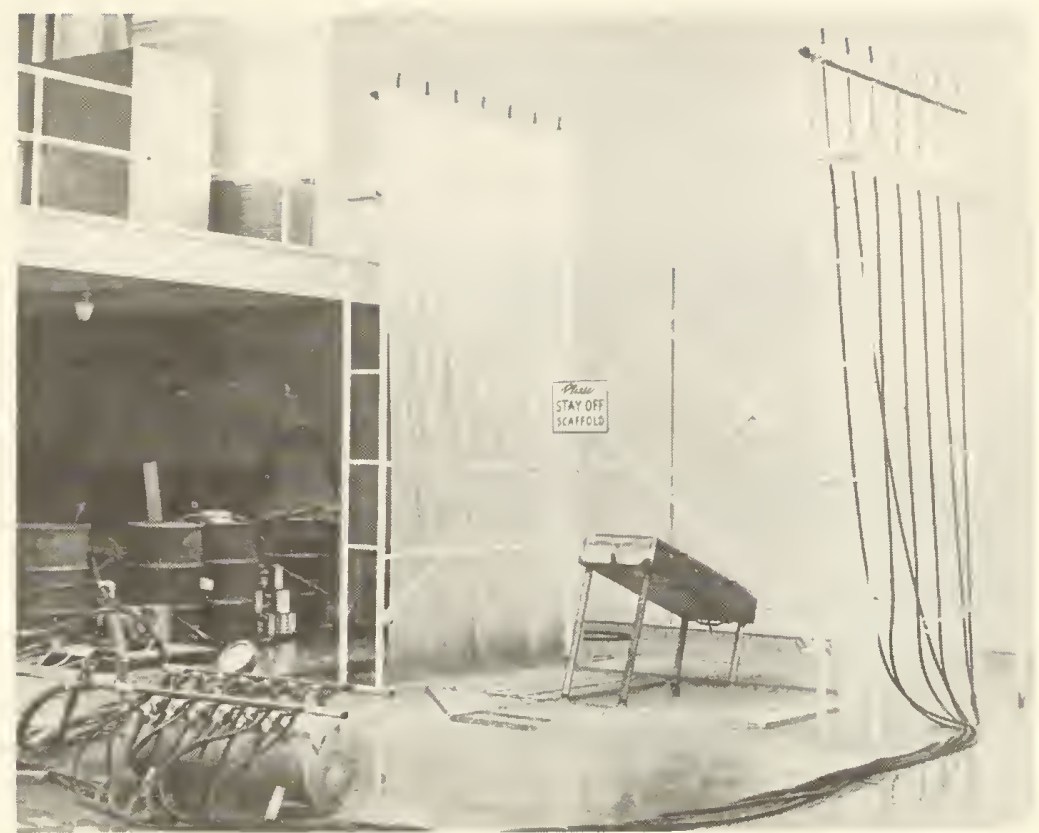

12 feet above the concrete floor and the hole in the end disc of each nozzle was reduced from 0.125 to 0.104 inch (fig. 1). These modifications greatly increased the fall distance of the drops and reduced the average drop size. The range of drop sizes for both the 3- and 7 -inch per hour rainfall intensities varied from 1 ess than $0.5 \mathrm{~mm}$. to slightly more than $5.0 \mathrm{~mm}$. At 7 inches per hour intensity, the average drop size was $1.87 \mathrm{~mm}$. and the $D_{50}$ drop size, $13.55 \mathrm{~mm}$. For the 3-inch-per-hour intensity, the average drop size was $1.91 \mathrm{~mm}$. and the $D_{50}$ size, $3.09 \mathrm{~mm}$.

All surface runoff of both water and soil particles was collected and weighed continuously throughout each run. One-pint runoff samples were collected periodically during each run to determine the concentration of soil material in the runoff.

Soil splash was collected all around the perimeter of the plot. Four concentric interlocking trays, each of which was 9 inches wide, were placed around each side and the upper end of the plot. Soil splash at the foot of the plot was collected in one large, unsegmented pan (fig. 1).

After each 30-minute run, a new plot was prepared. In a11, 18 runs were made using three soil types, each on three different slopes at two rainfall intensities.

The size distribution for both particles and water-stable aggregates was determined for all soil samples by using a wash bottle to gently wash the soil sample through a set of nested 3 -inch sieves.

We desired to use a single parameter to express the aggregate- and particle-size distributions. Since erosion is basically a work process, the size distribution

${ }^{1}$ The $D_{50}$ drop size is that size at which 50 percent of the water comes in drop sizes larger than the $D_{50}$ and 50 percent in drop sizes smaller than the $D_{50}$. 
parameter should be weighted more heavily by large-size fractions than by small-size fractions. This was accomplished by using the mean weight-diameter (Van Bavel 1949).

$$
\begin{aligned}
\text { MWD }= & \sum_{i=1}^{n} \bar{X}_{i} W_{i} \\
\text { where } \bar{X}_{i}= & \text { mean diameter of each size fraction in millimeters. } \\
W_{i}= & \begin{array}{l}
\text { proportion of the total sample weight in the corresponding } \\
\text { size fraction. }
\end{array}
\end{aligned}
$$

In addition to the mean weight-diameter, the percent of particles and water-stable aggregates greater than $2 \mathrm{~mm}$. was measured.

\section{Results}

\section{SOIL EROSION BY OVERLAND FLOW}

Cursory examination of table 1 reveals that the texture of the Wasatch clay soil is very different from the two granitic soils. However, on the basis of preliminary testing the effects of the soil variables appeared to be consistent across soil types. Therefore, the results from all test runs on the three soils were grouped together for regression analysis. A total of 18 test runs (three soils on three degrees of slope steepness at two rainfall intensities) were analyzed.

The weight of soil material washed off the plot was used as the dependent variable in regression analysis. Several soil and nonsoil factors were used as independent variables. The interaction mode1 illustrated in figure 2 explains over 96 percent of

Figure 2.--The relationship between soil erosion by overzand flow, rainfalz intensity, slope steepness, and the proportion, z, of soil particles and aggregates greater than $2 \mathrm{~mm}$. Each of the three regression surfaces represents a different $z$ value. The numbers at the comers of each surface represent the comount of soiz erosion in grams $\left(r^{2}=0.96\right)$.

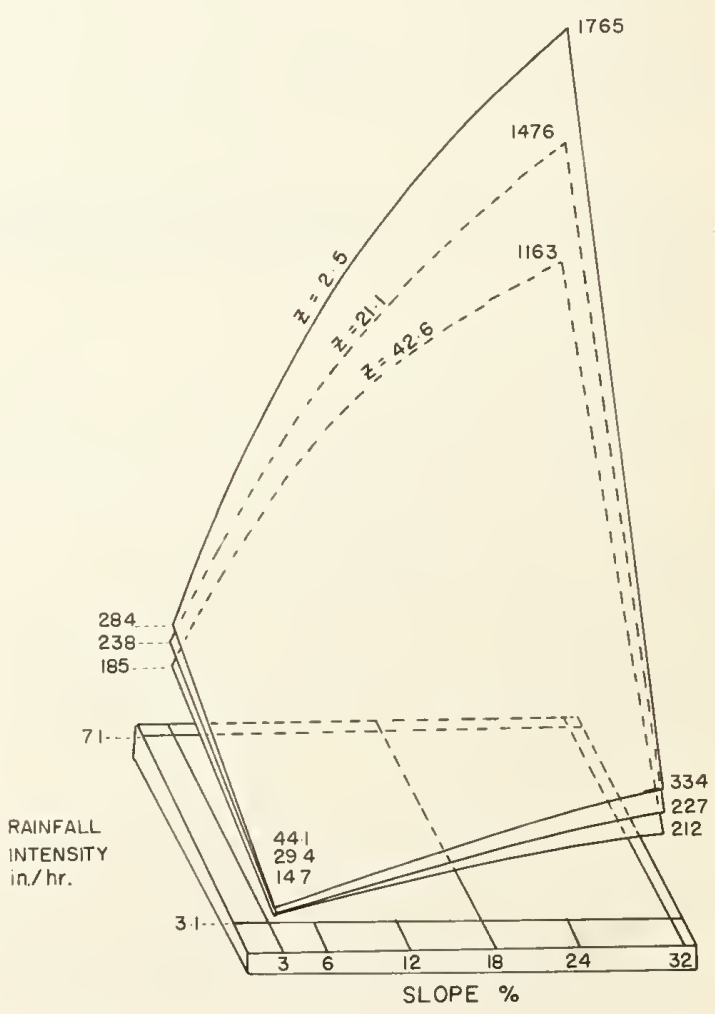


the variance in soil erosion by overland flow $\left(r^{2}=0.963\right)$. This model clearly shows the effect of the interaction between slope steepness and rainfall intensity on erosion by overland flow. The amount of soil that is eroded by overland flow is relatively small when either slope steepness or rainfall intensity is minimized, but it increases more than five times when both slope steepness and rainfall intensity are maximized. The effect of this interaction is modified by the percent of particles and water-stable aggregates greater than $2 \mathrm{~mm}$. As the proportion of particles and waterstable aggregates greater than $2 \mathrm{~mm}$. increases, the soil erosion amounts decrease. Each of the regression surfaces illustrated in figure 2 represents a specified proportion of soil material greater than $2 \mathrm{~mm}$. (i.e., 2.5, 21.1, or 42.6 percent).

The magnitude of deviations of the observed data from regression varied with values of the independent variables. For convenience in summarizing this information, observations were divided into two groups. Group 1 includes observations on 18- and 32-percent slopes and at high-rainfall intensity. Group 2 includes observations on the $2 \frac{1}{2}$ percent slope at high-rainfall intensity and on all slopes at low-rainfall intensity. The average and maximum absolute deviations from regression in group 1 were 158.1 and $264.1 \mathrm{~g} .$, respectively. Mean soil erosion for group 1 was $1262.3 \mathrm{~g}$. In group 2, the average and maximum absolute deviations were 24.8 and $66.2 \mathrm{~g}$., respectively; the mean was $190.2 \mathrm{~g}$.

Average deviation is 13 percent of the mean for both groups. These deviations are well within acceptable limits.

To examine the effects of the slope steepness-rainfall intensity interaction without any soil effect, the percent of particles and water-stable aggregates greater than $2 \mathrm{~mm}$. was removed from the regression model (fig. 2). The resulting $\mathrm{r}^{2}$ was 0.901 , compared to an $\mathrm{r}^{2}$ of 0.963 for the complete model. Therefore, the proportion of soil material greater than $2 \mathrm{~mm}$. explains an added 6 percent of the variance associated with soil erosion by overland flow. But since slope and rainfall intensity account for 90 percent of the variance in soil amounts eroded by overland flow, only 10 percent could be accounted for by added variables. Under these test conditions, the soil factors are much less important than rainfall intensity and slope steepness.

Six soil variables were measured for each of these tests: (1) the percent of particles and water-stable aggregates greater than $2 \mathrm{~mm}$., (2) the percent of particles less than 61 microns as determined by wet-sieve analysis, (3) total silt plus clay divided by the mean weight-diameter (Kemper and Chepil 1965), (4) the percent of particles and water-stable aggregates between $0.061-2.0 \mathrm{~mm}$, (5) bulk-density, and (6) the mean weight-diameter. Variables (1) and (6) were highly correlated, $r^{2}=0.996$. Since variable (1) was slightly more sensitive than (6) and easier to obtain, the mean weightdiameter, (6), was not used.

The first five soil variables mentioned above were used in a multiple regression analysis with soil eroded by overland flow as the dependent variable. No additive combination of variables nor their transformations were found that explained more than 27 percent of the variance in soil amounts eroded by overland flow. To examine the relative strength of individual soil variables, several models were used. All of these models involved the slope-rainfall intensity interaction and a single soil variable. These models indicated that the percent of particles and aggregates between 61 and 2,000 microns and the percent of particles and aggregates greater than $2 \mathrm{~mm}$. are the most important soil variables affecting soil erosion by overland flow. This result agrees in general with the findings of several other studies made on forest or range soils (Wooldridge 1965; Packer 1967; Ellison 1945). 
The mean particle size of the soil that was removed from the plot by overland flow was consistently smaller than the mean particle size of the original soil. Based on the MWD for all samples, the mean particle size of the original soil was $0.945 \mathrm{~mm}$., that of the runoff samples was $0.620 \mathrm{~mm}$, a 38 -percent reduction.

\section{SOIL SPLASH}

Splash erosion is the initial phase of the water erosion process. For the most part, raindrops provide the detaching force prerequisite for transporting soil particles by the sheet of surface detention water. Even on level areas where net erosion is small (especially on bare soils) as much as 60 tons of soil per acre per hour may be detached and splashed into the air. As slope steepness increases, discharge and velocity of surface water also increases and, correlatively, the rate of soil removal.

Soil splash is not difficult to measure in a laboratory study, but it is difficult to interpret the results of such measurements. In plot studies, soil that is splashed off the plot is "lost"; it is not subject to resplash or to further movement by the sheet of surface detention water. In the field, soil splash is not "lost," but remains available for further movement by splash or transport by the sheet of surface detention water. No satisfactory method has been developed to handle this problem.

On any inclined soil mass subject to raindrop impact, only a portion of the total splash goes in a downhill direction; the balance is splashed laterally or uphill. Neglecting wind effects, the proportion of downhill splash to total splash is largely a function of the slope angle. Downhill raindrop splash and slope angle are directly related, up to some critical slope angle. At that angle,virtually all splashed soil goes downhill.

The downhill component of raindrop splash erosion was not measured directly in this study. The four sidepans on each side of the soil plot contained both the downhill and uphill components of raindrop splash. However, the pan at the bottom of the plot did contain only that soil material that was splashed in a downhill direction. But, the amount of soil splashed into the bottom pan was less than the total downhill splash because some downhill splash was caught in the sidepans.

On the assumption that the same factors affect both bottom pan catch and total downhill raindrop splash, the amount of soil material splashed into the bottom pan was analyzed by regression methods. The weight of soil material splashed into the bottom pan by raindrop action was used as the dependent variable. Rainfall intensity, slope steepness, soil bulk density, and the percent of soil particles and water-stable aggregates between 61 and 2,000 microns (sand-size soil material) were used as independent variables. The regression model, illustrated in figures 3A and 3B, explains nearly 97 percent of the variance associated with splashed soil material that was caught in the bottom pan $\left(R^{2}=0.966\right)$.

Figures $3 \mathrm{~A}$ and $3 \mathrm{~B}$ show the effect of the strong interaction between slope steepness and rainfall intensity on raindrop splash erosion. Note that raindrop-splash erosion is quite small on the most shallow slope, even at the greatest rainfall intensity. This does not mean that less soil was splashed on the shallow slope, but that less soil was splashed and transported downhill on the shallow slope. Maximum amounts of soil are eroded by raindrop splash where slope steepness and rainfall intensity are greatest. Pretreatment soil bulk density and the amount of soil-splash erosion are directly related. However, the effect of bulk density on soil splash is more pronounced as slope steepness increases; i.e., at a rainfall intensity of 3.1 inches per hour, the difference in the weights of soil splash between bulk densities of 0.95 and $1.37 \mathrm{~g}$. per $\mathrm{cm}{ }^{3}$ is only $10 \mathrm{~g}$. at 3 percent slope, but $289 \mathrm{~g}$. at 32 percent slope (fig. $3 \mathrm{~A}$ ). Each of the three regression surfaces in figures $3 A$ and $3 B$ represent a different value of pretreatment soil bulk density, namely, $0.95,1.16$, or $1.37 \mathrm{~g}$. per $\mathrm{cm}^{3}$ The effect of 



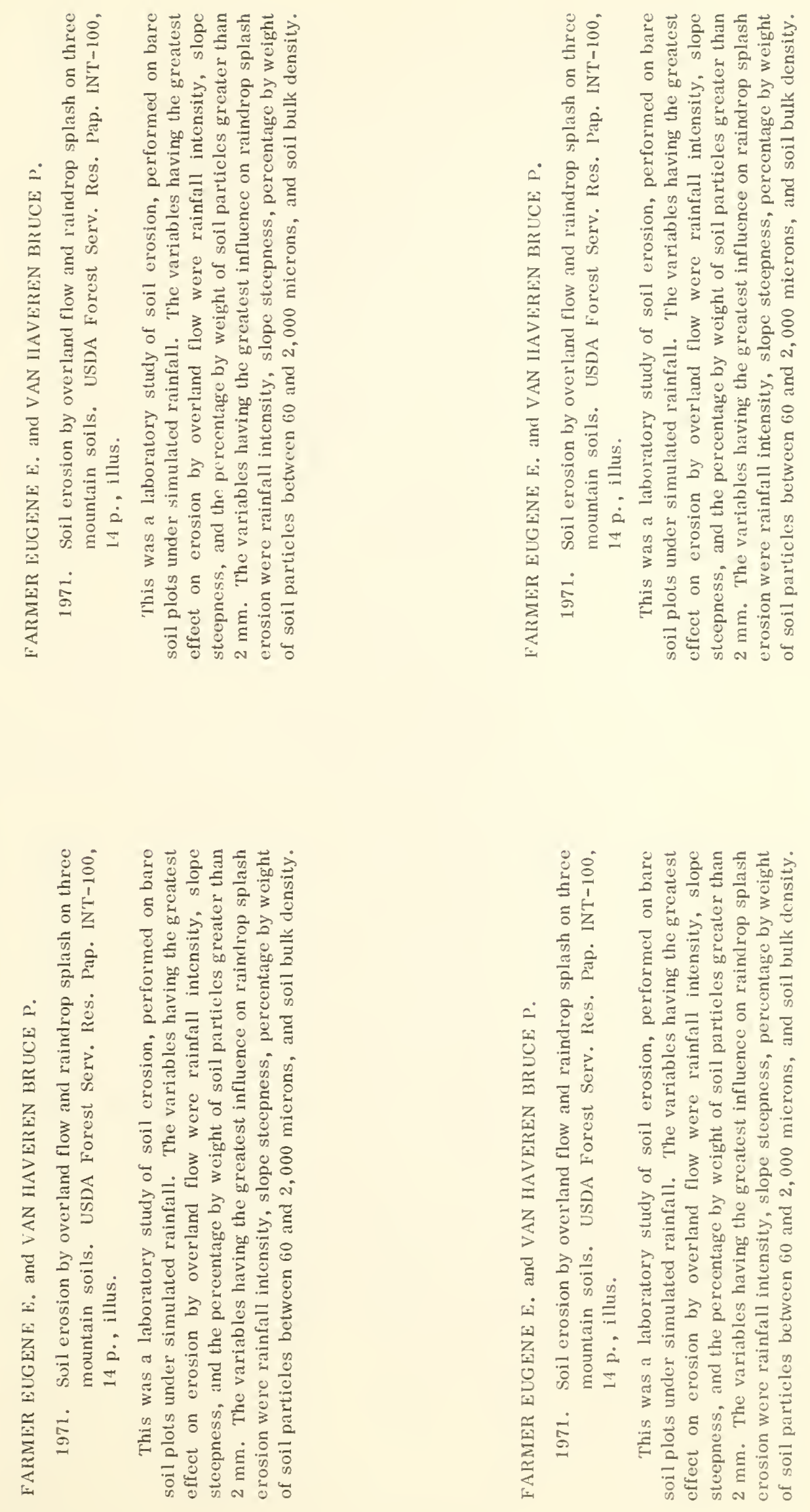

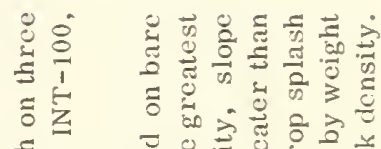

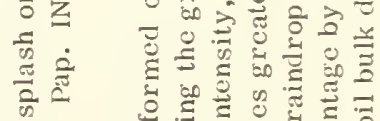

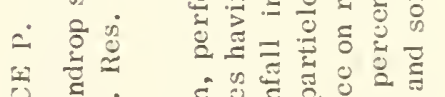

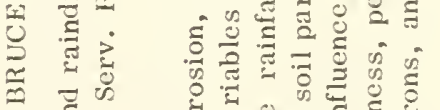

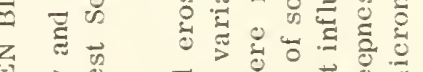

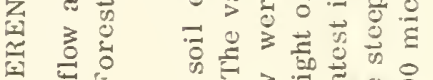

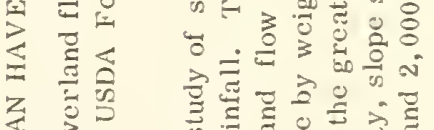

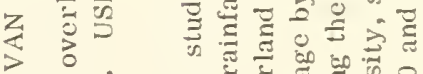

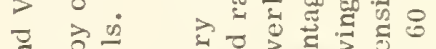

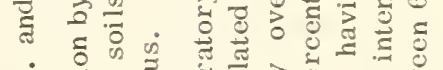

क क ज

ต

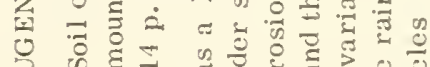

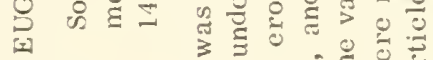

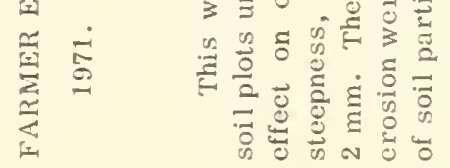




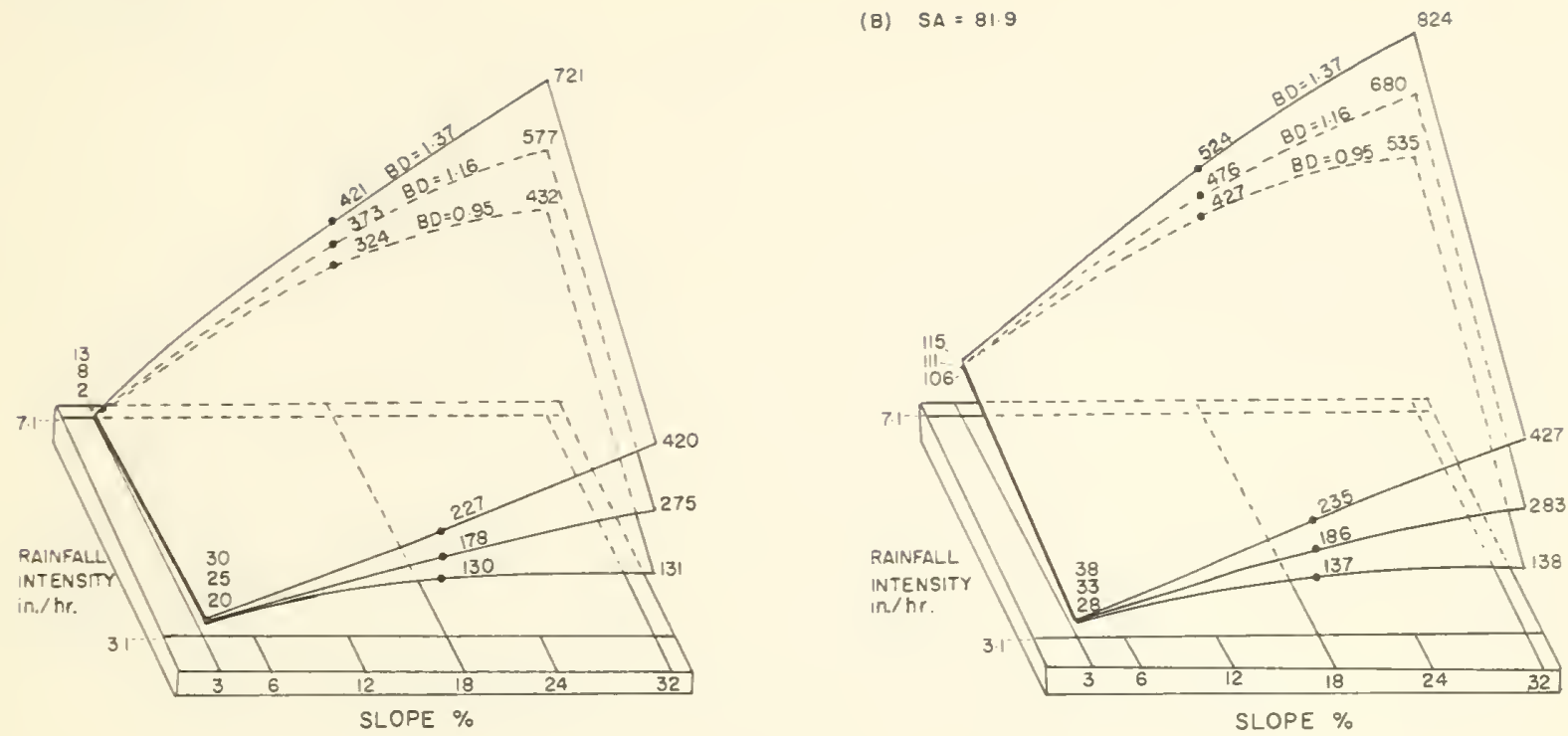

Figure 3.--The relationship between measured soil splash eroded into the bottom pan, rainfall intensity, slope steepness, soil bulk density, and the percent of soil particles and water-stable aggregates between 61 and 2,000 microns, $S A,\left(R^{2}=0.97\right)$. The nombers at the comers of each surface indicate the amount of soil splash in grans. Figure $3 A$ shows the relationship for three values of bulk density and an $S A$ of 55.1 percent; figure $3 B$ is similar except $S A$ is 81.9 percent.

the percent sand-size material (not necessarily sand grains) is also directly related to raindrop erosion. This is illustrated by comparing figure $3 \mathrm{~A}$ with figure $3 \mathrm{~B}$. As the proportion of sand-size material increases from 55.1 to 81.9 percent, the weight of soil eroded by raindrop splash also increases.

The average and maximum absolute deviations from regression were $32.9 \mathrm{~g}$. and $79.9 \mathrm{~g}$., respectively. The mean weight of soil eroded by raindrop splash was $249.0 \mathrm{~g}$.

If the two soil factors, bulk density and proportion of sand-size material, are not included in the interaction model, the resulting $\mathrm{R}^{2}$ is 0.82 . This means that the slope steepness-rainfall intensity interaction accounted for 82 percent of the variance associated with soil-splash erosion; soil bulk density and the proportion of soil material in the sand-size range accounted for approximately 15 percent of the variance.

The proportion of total splash going downhill is quite difficult to measure, but can be estimated on a rational basis (Ekern 1951). On a horizontal soil surface, the soil splash resulting from raindrop impact should be equally divided in all directions. However, assume a unit force of raindrop impact strikes an inclined soil surface in a vertical plane. This impulsive force will result in two component forces, one parallel to the slope in a downhill direction, the second normal to the slope (fig. 4). 
Figure 4.--The resolution of a vertical unit vector force of raindrop impact striking an inclined surface.

Then:

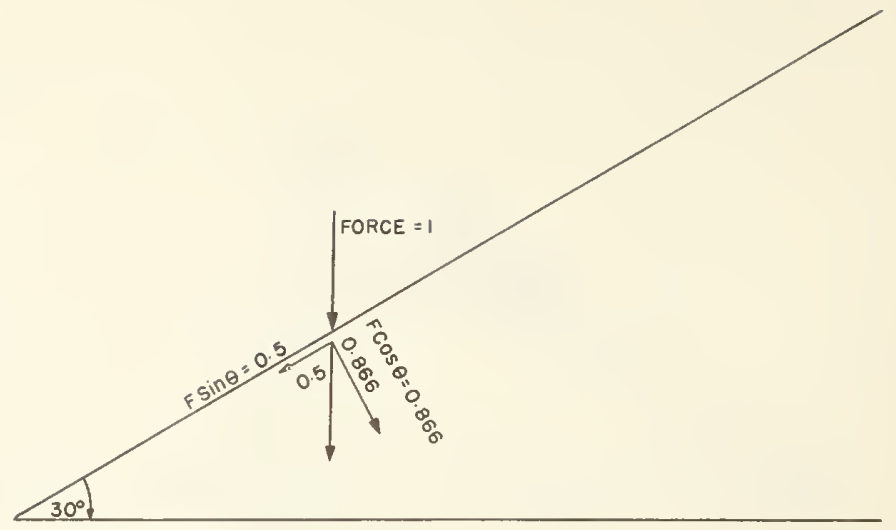

$P f=V f \operatorname{Sin} \theta$

$\mathrm{EQ}(1)$

where:

$$
\begin{aligned}
& \text { Pf }=\text { magnitude of the force parallel to the slope; } \\
& V f=\text { magnitude of the force vertical to the slope; and } \\
& \theta=\text { slope angle, degrees. }
\end{aligned}
$$

And :

$$
N f=V f \operatorname{Cos} \theta
$$

where:

$$
\mathrm{Nf}=\text { magnitude of the force normal to the slope. }
$$

The soil splash resulting from the normal component is assumed to be displaced equally up and down the slope. Therefore, the downslope component of soil splash resulting from a unit force of raindrop impact is expected to be:

$$
S_{D}=\sin \theta+1 / 2 \operatorname{Cos} \theta
$$

where:

$$
\mathrm{S}_{\mathrm{D}}=\text { the proportion of total soil splash moving downhill }
$$

It is interesting to note that EQ(3) predicts that virtually all soil splash resulting from vertical raindrop impact will go in a downhill direction on all slopes equal to or greater than $37^{\circ}$ (75-percent slope). However, this hypothesis was not tested.

The total amount of soil splashed from the soil plot was measured for each of the 18 test runs. EQ(3) was used to calculate the downslope component of the measured total splash. These data were then analyzed by multiple regression methods. Total calculated downslope soil splash was used as the dependent variable. The independent variables were the same as those for the soil splashed into the bottom pan (i.e., slope steepness, rainfall intensity, soil bulk density, and the proportion of total soil particles and water-stable aggregates between 61 and 2,000 microns in diameter). The resulting regression model (figs. 5A and 5B) explains over 92 percent of the variance associated with the calculated total downslope soil-splash erosion, $\left(R^{2}=0.924\right)$. 
(A) $S A=551 \%$

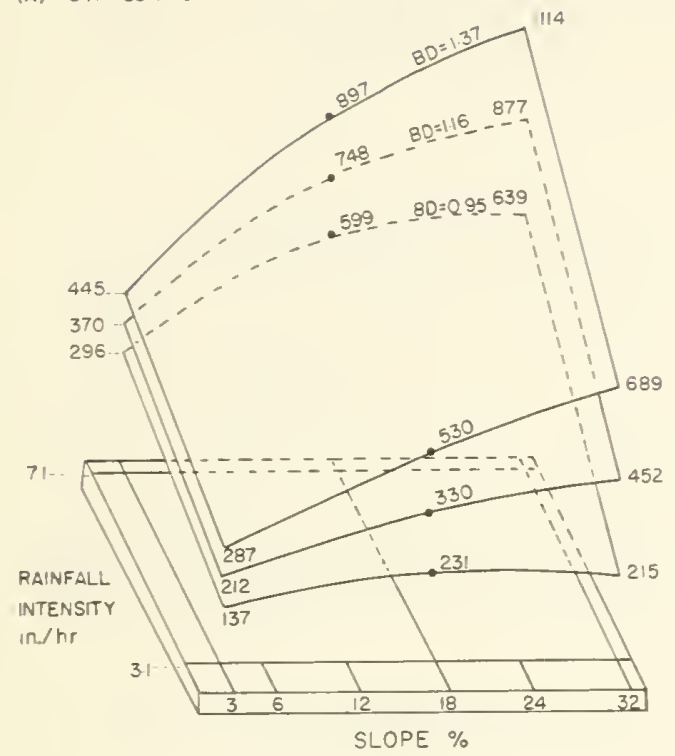

(B) $S A=81.9 \%$

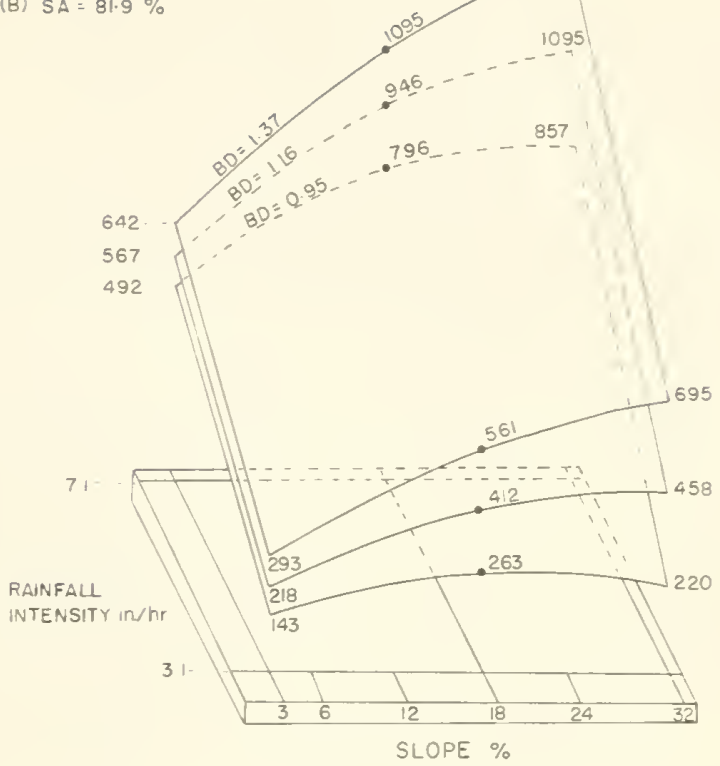

Figure 5.--The relationship betieen calculated downslope soil splash due to raindrop impact, rainfall intensity, slope steepness, soil buik density, and the percent of soil particies and water-stable aggregates between 61 and 2,000 microns, $S A,\left(R^{2}=0.92\right)$. The numbers at the comers of each surface indicate the amount of soil splash in grams. Figure $5 \mathrm{~A}$ shows the relationship for three values of buik density and an $S A$ of 55.1 percent; figure $5 B$ is similar except $S A$ is 81.9 percent.

Each of the independent variables associated with the models for bottom pan splash and calculated total downslope splash have similar effects. There is the strong interaction between slope steepness and rainfall intensity; bulk density and the proportion of sand-size material both act directly to increase the downslope component of total soil splash.

The average and maximum absolute deviations from the regression model are $66.0 \mathrm{~g}$. and $174.1 \mathrm{~g}$., respectively. The mean weight of downslope splash was $538.8 \mathrm{~g}$. These deviations are about twice as large as those for the bottom pan model (figs. $3 \mathrm{~A}$ and 3B). This indicates that by calculating the downslope splash component we have added unexplained variation as compared to measured splash in the bottom pan. The addition of unexplained variation is also indicated by the reduction in $\mathrm{R}^{2}$. Even so, the relatively high $\mathrm{R}^{2}$ associated with the calculated downslope model is evidence that EQ(3) gave a reasonable estimate of the true downslope component of soil splash due to raindrop impact. This evidence is strengthened by the fact that the same parameters that explain a large proportion of the variance associated with measured splash in the bottom pan also explain a large proportion of the variance associated with calculated downslope soil splash. 
If the independent soil variables are dropped from the regression model illustrated in figures $5 \mathrm{~A}$ and $5 \mathrm{~B}$, the resulting $\mathrm{R}^{2}$ is 0.75 . Therefore, while the slope steepnessrainfall intensity interaction accounts for 75 percent of the variance associated with calculated total downslope soil splash, the two soil variables account for an additional 17 percent of the variance. This result is very similar to that of the bottom pan model (figs. $3 A$ and $3 B$ ).

Five soil variables--percent of soil particles and aggregates greater than $2 \mathrm{~mm}$, percen $\ddot{t}$ of soil particles and aggregates between.61_and 2,000 microns, silt plus clay divided by the mean weight diameter, silt plus clay, and soil bulk density--were used in multiple regression analysis with the calculated downslope splash as the dependent variable. The resulting regression equation gave an $R^{2}$ of only 0.31 . The failure of soil variables (in the absence of nonsoil variables) to explain an acceptable proportion of the variance associated with soil erosion has been consistent throughout this study. In order to explain as much as one-third of the variance associated with any type of soil erosion on the plots, the slope steepness and rainfall intensity factors must be accounted for. Soil physical factors increase the strength of the regression, but are unable to produce an acceptable regression equation by themselves. On the other hand, the interaction between slope steepness and rainfall intensity explained at least 75 percent of the variance associated with soil erosion.

The distance that soil was splashed off the plot was assessed by the average weighted distance computed for the side splash trays only:

Average weighted distance $=\frac{\sum_{i=1}^{4} X_{i} Z_{i}}{\sum_{i=1}^{4} Z_{i}}$

where:

$\begin{aligned} \mathrm{X} i= & \text { distance from the edge of the plot to the center of a splash tray } \\ & \text { in centimeters }\end{aligned}$

$\mathrm{Zi}$ = weight of splashed soil in a given splash tray in grams.

The average weighted distance of splashed soil material did not vary greatly between the three soil types. It was $25.18 \mathrm{~cm} ., 25.31 \mathrm{~cm}$., and $26.42 \mathrm{~cm}$. for the lowand high-elevation granitics and the Wasatch clay, respectively. At a rainfall intensity of 3 inches an hour the average weighted distance was $24.82 \mathrm{~cm}$.; at 7 inches an hour, $26.45 \mathrm{~cm}$. The distance increased more noticeably with slope. It was $22.77 \mathrm{~cm}$., $25.15 \mathrm{~cm}$, and $28.98 \mathrm{~cm}$. for $2 \frac{1}{2}-, 18$, and 32 -percent slopes, respectively. These splash distances are for soil material splashed only a single time. Splash distance was not measured directly downslope; so the downslope vector may not be equal to the distances indicated above. However, on steep slopes with multiple splashes, surface soil material could be moved considerable distances downslope irrespective of transport by overland flow.

The size (diameter) of splashed soil material varied inversely with the distance that it was splashed (table 2). As was expected, most of the splashed soil material was in the sand and silt fractions. However, both gravel and clay fractions were found in the splashed soil. Soil material in the clay sizes ordinarily was splashed as aggregates (Wasatch clay) or as clay particles adhering to sand and gravel (Idaho granitics). 
Table 2.-llean weight diometers in mizlimeters for each of the pretreatment soils and for splashed soil material by splash jistances

\begin{tabular}{|c|c|c|c|c|c|c|}
\hline \multirow{3}{*}{$\begin{array}{l}\text { Percent } \\
\text { slope }\end{array}$} & \multirow{3}{*}{$\begin{array}{l}\text { Soil } \\
\text { type }\end{array}$} & \multirow{3}{*}{$\begin{array}{l}\text { Pretreatment } \\
\text { soil }\end{array}$} & \multicolumn{4}{|c|}{ Splashed soil } \\
\hline & & & \multicolumn{4}{|c|}{ Splash distance in centimeters } \\
\hline & & & 11 & 34 & $5 \quad 57$ & $: \quad 80$ \\
\hline \multirow{3}{*}{$2 \frac{1}{2}$} & $\begin{array}{l}\text { High-elevation } \\
\text { granitic }\end{array}$ & 1.254 & 0.992 & 0.614 & 0.444 & 0.404 \\
\hline & $\begin{array}{l}\text { Low-elevation } \\
\text { granitic }\end{array}$ & 1.164 & 1.178 & .694 & .495 & .410 \\
\hline & Wasatch clay & .317 & .386 & .311 & .316 & .272 \\
\hline \multirow{3}{*}{18} & $\begin{array}{l}\text { High-elevation } \\
\text { granitic }\end{array}$ & 1.497 & .808 & .628 & .476 & .384 \\
\hline & $\begin{array}{l}\text { Low-elevation } \\
\text { granitic }\end{array}$ & .898 & .857 & .578 & .506 & .421 \\
\hline & Wasatch clay & .585 & .461 & .373 & .292 & .288 \\
\hline \multirow{3}{*}{32} & $\begin{array}{l}\text { High-elevation } \\
\text { granitic }\end{array}$ & 1.466 & .998 & .688 & .662 & .455 \\
\hline & $\begin{array}{l}\text { Low-elevation } \\
\text { granitic }\end{array}$ & .951 & .875 & .719 & .510 &.+0 \\
\hline & Wasatch clay & .372 & .355 & .324 & .248 & .261 \\
\hline
\end{tabular}

\section{ERODIBILITY RANKING BY SOIL TYPE}

In order to rank these soils according to their relative erodibility, the regression models illustrated in figures 2 and 5 were solved by using values of the independent variables chosen so as to either maximize or minimize erosion. Each of the soil variables was set at either the maximum or minimum value observed within each soil type (table 3). Soil erosion by overland flow varies directly with rainfall intensity and slope and inversely with the percent of soil particles and aggregates greater than $2 \mathrm{~mm}$; consequently, the calculated erosion was maximized by using the greatest rainfall intensity, the steepest slope, and the lowest percent of soil particles and aggregates greater than $2 \mathrm{~mm}$. Conversely, soil erosion by overland flow is minimized by using the lowest rainfall intensity, the most shallow slope, and the greatest percent of particles and aggregates greater than $2 \mathrm{~mm}$. Soil erosion due to raindrop splash varies directly with both the soil bulk density and the percent of particles and aggregates between 61 and 2,000 microns. Therefore, raindrop-splash erosion was maximized by using the largest values of rainfall intensity, slope, bulk density, and percent soil material between 61 and 2,000 microns, and minimized by using the smallest values of these variables. The results of these calculations are presented in table 4.

The high-elevation granitic soil appears to be the least erodible of these three soil types. The low-elevation granitic and Wasatch clay types are about equally erodible on a total weight basis; the Wasatch clay is more susceptible to soil loss by: overland flow than the low-elevation granitic, but less susceptible to erosion by raindrop splash. 
Table 3.--The observed range and mean values of three soil factors on each of three soil types

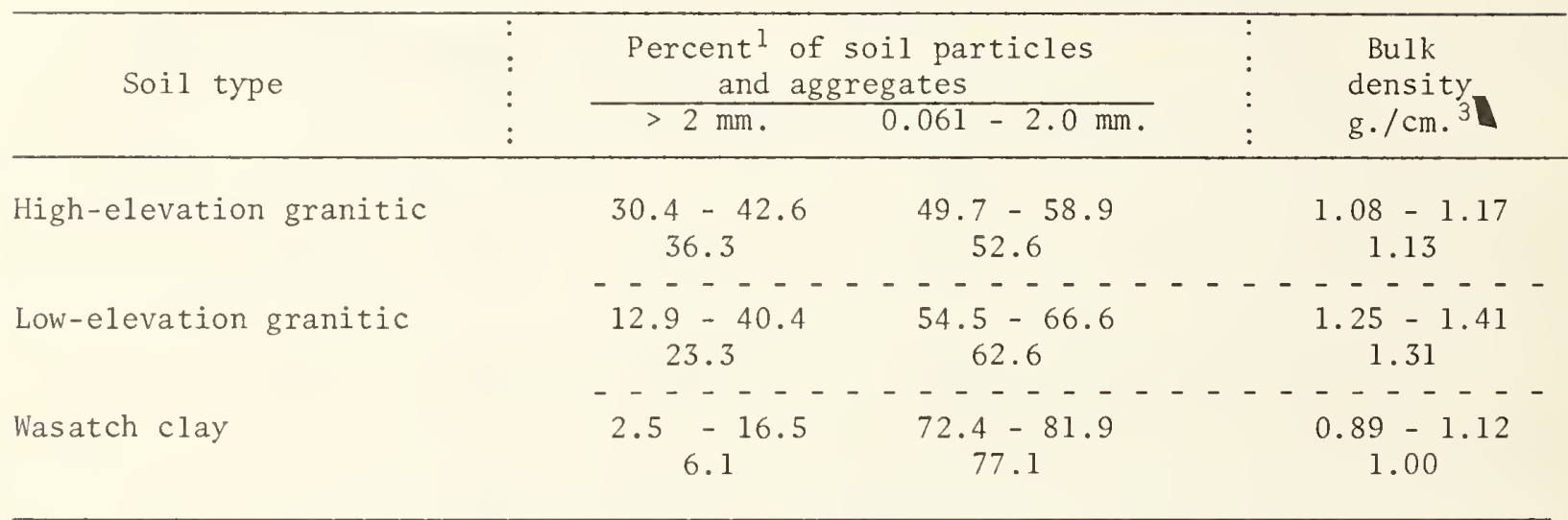

${ }^{1}$ As determined by wet-sieving.

Table 4.--Calculated values of minimum and maximum erosion due to overland flow and raindrop splash in grams

\begin{tabular}{|c|c|c|c|c|c|c|}
\hline \multirow[t]{2}{*}{ Soil type } & \multirow{2}{*}{$\begin{array}{l}: \\
\vdots \\
:\end{array}$} & \multicolumn{2}{|c|}{$\begin{array}{l}\text { Soil erosion by } \\
\text { overland flow }\end{array}$} & \multirow{2}{*}{$\begin{array}{l}: \\
:\end{array}$} & \multicolumn{2}{|c|}{$\begin{array}{l}\text { Soil erosion by } \\
\text { raindrop splash }\end{array}$} \\
\hline & & Minimum & Maximum & & Minimum & Maximum \\
\hline High-elevation granitic & & 20 & 1,306 & & 150 & 961 \\
\hline Low-elevation granitic & & 20 & 1,572 & & 237 & 1,134 \\
\hline Wasatch clay & & 31 & 1,730 & & 112 & 1,075 \\
\hline
\end{tabular}




\section{Discussion}

Soil texture and other soil physical properties indicate that the Wasatch clay soil used in this work is greatly different from the two granitic soils. As a consequence, the soil variables used in these regression analyses covered a wide range of values (table 3 ). The effects of the soil variables were consistent across soil types. During the analyses for the effect of soil variables, two soil-size fractions were used: (1) greater than $2 \mathrm{~mm}$. and (2) between 61 and 2,000 microns. From the analyses, we were unable to distinguish between the well-aggregated, fine clay soil and the poorly aggregated, coarse-grained granitic soils. Water-stable soil aggregates of a given size class behaved in the same manner as nonaggregated soil particles of the same size.

Stripped of vegetation, all three of these soils exhibit little resistance to erosive forces. High-intensity rainstorms over areas of sparse vegetal cover can be expected to produce tremendous quantities of sediment.

The regression models of soil erosion presented here are not intended for field prediction purposes, but to characterize relationships between the variables observed in the data. Rainfall intensity and slope steepness interact strongly to influence soil erosion by overland flow. This relation, however, is modified by the proportion of soil particles and water-stable aggregates greater than $2 \mathrm{~mm}$. in diameter. This latter factor is really a measure of soil coarseness.

Raindrop-splash erosion is also affected to a large degree by an interaction between rainfall intensity and slope steepness. The effect of soil particles and aggregates between 61 and 2,000 microns is additive and directly related to the amounts of soil splash. Apparently, sand-size material is especially susceptible to splash erosion. During splash erosion, an interaction also takes place between slope steepness and soil bulk density that is not completely understood. In fact, the statistical model for soil splash (figs. 5A and 5B) specifies this relationship imperfectly. On. the steep slope at low bulk density the model indicates a small decrease in splash erosion as compared to the medium slope. While splash erosion probably does not increase much between slopes of 18 and 32 percent with soil bulk density less than 1.00 , it is not expected to decrease. Ignoring the effect of bulk density, EQ(3) predicts an 11 percent increase in downslope splash for 32-percent slope compared to 18-percent slope. However, an increase in soil bulk density increases the amount of soil splash erosion. On most forest and range soils bulk density exhibits a seasonal increase from the spring to the fall (Laycock and Conrad 1967). Soil splash erosion can also be expected to exhibit an increase from spring to fall.

The strength of the interaction between rainfall intensity and slope steepness is at least a full order of magnitude greater than that of any soil variable, and at least four times as great as any combination of soil variables made in this study. Therefore, it appears that before real expertise can be developed in soil erosion problems due to storm rainfall, information must be assembled on the rainfall patterns and characteristics as well as on topographic effects. Conversely, much of the work in the soil erosion literature describing the effect of soil factors on soil erosion has been concerned with explaining (at best) a small proportion of the variation associated with soil erosion. Comparative erodibilities of soils have been made on the basis of soil factors; these comparisons implicitly assume that rainfall characteristics and topographic effects are equal. Under field conditions this assumption is very questionable. While vegetation was omitted from this study, any realistic evaluation of natural soil erosion must give full recognition to the potentially overwhelming effects of vegetation. 


\section{Literature Cited}

Bryan, Rorke B.

1968. The development, use and efficiency of indices of soil erodibility.

Geoderma 2, 1968-69: 5-26.

Ekern, P. C.

1951. Raindrop impact as the force initiating soil erosion. Soil Sci. Soc. Amer. Proc. 15: 7-10.

Ellison, W. D.

1945. Some effects of raindrops and surface-flow on soil erosion and infiltra-

tion. Amer. Geophys. Union Trans. 26: 415-429.

Kemper, W. D., and W. S. Chepil

1965. Size distribution of aggregates. P. 505, in: Methods of Soil Analysis, Part I, Physical and mineralogical properties, including statistics of measurement and sampling. Madison, Wisconsin: Amer. Soc. of Agron.

Laycock, W. A., and P. W. Conrad

1967. Effect of grazing on soil compaction as measured by bulk density on a high elevation cattle range. J. Range Manage. 20 (3): 136-140.

Packer, Paul E.

1957. Intermountain infiltrometer. USDA Forest Serv., Intermountain Forest and Range Exp. Sta. Misc. Pub. 14, 41 p., Ogden, Utah.

Packer, Paul E.

1967. Criteria for designing and locating logging roads to control sediment. Forest Sci. 13: 2-18.

Smith, Dwight D., and Walter H. Wischmeier

1962. Rainfall erosion. Advances in Agron. 14: 109-148.

Van Bavel, C. H. M.

1949. Mean weight diameter of soil aggregates as a statistical index of aggregation. Soil Sci. Soc. Amer. Proc. 14: 20-23.

Wischmeier, Walter $\mathrm{H}$.

1959. A rainfall erosion index for a universal soil-loss equation. Soil Sci. Soc. Amer. Proc. 23: 246-249.

Wischmeier, Walter H., and Dwight D. Smith

1958. Rainfall energy and its relationship to soil loss. Amer. Geophys. Union Trans. 39: 285-291.

Wooldridge, D. D.

1965. Soil properties related to erosion of wildland soils in central Washington. Pp. 141-152, in: Forest-Soil Relationships in North America. Corvallis, Oregon: Oregon State Univ. Press. 
Headquarters for the Intermountain Forest and Range Experiment Station are in Ogden, Utah. Field Research Work Units are maintained in:

Boise, Idaho

Bozeman, Montana (in cooperation with Montana State University)

Logan. Ltah (in cooperation with Utah State University)

Missoula, Montana (in cooperation with University of Montana)

Moscow, Idaho (in cooperation with the University of Idaho)

Provo, Utah (in cooperation with Brigham Young University) 
